LESZEK KAJZER

Instytut Archeologii

Uniwersytetu Łódzkiego

\title{
O PIERWSZYCH I DRUGICH NARODZINACH SŁÓW KILKA
}

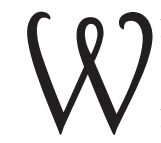
maju 2015 r. Uniwersytet Łódzki hucznie obchodził swoje 70-lecie. Nie jest to może tak okrągła rocznica jak np. 75-lecie, ale doceniając realia wzmocnione magicznymi znaczeniami siódemki, przyznać wypada, iż jest to jubileusz wart odnotowania i chwili refleksji. Dzieciństwo autora tego tekstu upłynęło najpierw w przekonaniu, że ma tyle lat, „ile Polska Ludowa”. Natomiast wczesna dojrzałość, spędzona już na studiach, zdominowana była informacjami, iż oto mam niepowtarzalną okazję zdobywać wiedzę na "młodym uniwersytecie”. „Młodość” owej uczelni miała zresztą wiele znaczeń, z których może nie wszystkie chcemy sobie zbyt często przypominać. Tak to $\mathrm{w}$ przeciągu życia jednego pokolenia uczelnia młoda stała się, jeśli nie starą, to jedną ze starszych w naszym kraju. Pomijając sięgający wieku XIV Uniwersytet Jagielloński i Uniwersytet Warszawski z 1816 r., a zapominając o obu uczelniach z Kresów, pozostałe powstały już w wieku XX. W latach 1918-19 powołano do życia Katolicki Uniwersytet Lubelski i Uniwersytet Poznański, a bezpośrednio po drugiej wojnie światowej uniwersytety: lubelski (już w 1944 r.) oraz w 1945 r. łódzki, toruński i wrocławski, jeśli nie liczyć jego wcześniejszych, także jezuickich, korzeni. W ten sposób Uniwersytet Łódzki mieści się w pierwszej siódemce najstarszych państwowych polskich uczelni.

Choć czytelnik najnowszej, wydanej już w XXI w. Wielkiej Encyklopedii Powszechnej PWN pragnący poznać treść hasła „Historia sztuki” i szukający go pod literą "H” odsyłany jest do innego tomu, gdzie może o niej przeczytać w podhaśle pomieszczonym w „Sztukach plastycznych”, nie mam wątpliwości, że jest to nie tylko nauka historyczna, lecz także wielce liczący się składnik w pełni humanistycznego poznawania wysublimowanych aspektów rzeczywistości. Tak też ulokowana jest w strukturze naszych uniwersytetów, znajdując się na wydziałach grupujących całą humanistykę, zwanych 
dawniej „humanistycznymi”, a teraz już raczej na tych: historycznych, filozoficzno-historycznych, historyczno-pedagogicznych itp.

Powstały, jak się ogólnie i może nie do końca słusznie uważa, w dniu 24 maja 1945 r. Uniwersytet Łódzki był uczelnią, w której w roku akademickim 1945/1946 pracowało 530 osób, a studiowało nieco ponad 7 tys. studentów. Składał się z sześciu wydziałów. Trzy z nich (Lekarski, Stomatologiczny i Farmaceutyczny) utworzyły potem Akademię Medyczną, a wśród trzech pozostałych znalazł się Wydział Humanistyczny (obok Matematyczno-Przyrodniczego i Prawno-Ekonomicznego) ${ }^{1}$. Stanowił on strukturę zbudowaną z zakładów, w której skład wchodziły m.in. Zakład/Katedra Prehistorii ${ }^{2}$ (potem Archeologii) zorganizowana przez prof. Konrada Jażdżewskiego, Zakład/Katedra Estetyki kierowana przez prof. Mieczysława Wallisa i Zakład/Katedra Historii Sztuki Wacława Husarskiego. Owe trzy jednostki wymieniłem nieprzypadkowo, przypominając tym, że początków uniwersyteckiego uprawiania historii sztuki w Polsce należy szukać w trzeciej ćwierci XIX w. w UJ. Tam kierowana przez Józefa Łepkowskiego katedra łącząca archeologię i historię sztuki po przejściu profesora na emeryturę podzieliła się na dwie struktury, z których jedna stała się z czasem Katedrą Archeologii, a druga, powołana do życia w 1882 r. pod kierownictwem prof. Mariana Sokołowskiego, Katedrą Historii Sztuki. Uniwersyteckie korzenie obu nauk w realiach polskich były więc wspólne, a po 133 latach swoisty komentarz do tamtych wydarzeń nastąpił w Łodzi, gdzie od 2014 r. obie jednostki naukowo-dydaktyczne, czyli historia sztuki i archeologia, dzielą gmach przy ul. Uniwersyteckiej 3.

Zacznijmy jednak od początków, czyli pierwszych narodzin łódzkiej historii sztuki. Pierwsze pokolenie profesorów docierało na nowy uniwersytet z różnych stron, choć w literaturze na ogół podkreśla się, że uczelnię stworzyły dwie grupy uczonych: ta wywodząca się jeszcze z przedwojennej kadry Wolnej Wszechnicy Polskiej i ta przybywająca z różnych uczelni i innych miejsc pracy ${ }^{3}$. Z różnych stron przyszli też do Łodzi „ojcowie założyciele" historii sztuki, czyli W. Husarski i M. Wallis ${ }^{4}$. Pierwszy przed

${ }^{1}$ Por. liczne prace na temat początków naszej uczelni: Materiały do dziejów Uniwersytetu Łódzkiego. 1945-1950, red. B. Bararanowski, K. Duda-Dziewierz, Łódź 1952; Uniwersytet Łódzki 1945-1970, red. A. Kłoskowska, Łódź 1970 (publikacja oceniana bardzo krytycznie); B. Baranowski, K. Baranowski, Pierwsze lata Uniwersytetu Łódzkiego (1945-1949), Łódź 1985; eidem, Trudne lata Uniwersytetu Łódzkiego (1949-1956), Łódź 1990; K. Baranowski, Początki Łodzi akademickiej, Łódź 1993; J. Kita, S. Pytlas, Uniwersytet Łódzki w latach 1945-1995, Łódź 1996. Por. ostatnio: W. Puś, Zarys historii Uniwersytetu Łódzkiego 1945-2015, Łódź 2015, s. 11-17.

2 Początkowo Wydział składał się z zakładów, które w miarę czasu i przemian administracyjnych zmieniały nazwę, stając się katedrami.

${ }^{3}$ K. Baranowski, op. cit., s. 109 nn.

${ }^{4}$ J. Kita, S. Pytlas, Profesorowie Uniwersytetu Łodzkiego 1945-1994. Pro memoria, Łódź 1995. 
wojną związany był z Wolną Wszechnicą, gdzie w 1932 r. habilitował się w zakresie historii sztuki i do 1939 r. wykładał jako docent. W Łodzi pojawił się w początkach naszej uczelni, zostając profesorem nadzwyczajnym, ale równocześnie był osobą już po sześćdziesiątce (urodził się w Warszawie w 1883 r.), do tego mającą poważne kłopoty zdrowotne ${ }^{5}$. Dydaktyka nie wyczerpywała jego aktywności. Był także wystawiającym malarzem (w grupie Rytm), łącznie z zatrudnieniem w UŁ krótko pracował jako wojewódzki konserwator zabytków, tłumaczył teksty francuskie, włoskie i niemieckie, opracował liczne biogramy artystów polskich i zagranicznych, a zawodowo zainteresowany sztuką nowoczesną i nowożytną, pozostawił po sobie publikacje dotyczące głównie malarstwa, ale i podstawową monografię Sztuka Kazimierza Dolnego (wydanie pośmiertne 1953). Choroba płuc i serca spowodowała, że od 1948 r. przebywał głównie w sanatorium, a w 1949 r. zrezygnował z kierowania Katedrą Historii Sztuki. Schyłek życia spędził w sanatorium w Sokołowsku koło Wałbrzycha, ciężko chorując na płuca. Zmarł tam w $1951 \mathrm{r}$.

Mieczysław Wallis, podobnie jak W. Husarski kombatant wojny polsko-bolszewickiej, to wykształcony filozoficznie krytyk i historyk sztuki, który już w 1921 r. obronił pracę doktorską z filozofii napisaną pod kierunkiem Tadeusza Kotarbińskiego. Pracował jako nauczyciel, wykładowca, publikował teksty krytyczne i opracowywał hasła-biografie dla wydawanego w Lipsku słownika artystów Thiemego-Beckera. Zaraz po wojnie uzyskał stopień doktora habilitowanego i przyjechał do Łodzi, gdzie został profesorem nadzwyczajnym i kierownikiem Katedry Estetyki (od 1945 r.), a po odejściu prof. W. Husarskiego także kierownikiem Katedry Historii Sztuki (w latach 1951-1965). W roku akademickim 1955/1956 został też dziekanem Wydziału Filozoficzno-Historycznego. W 1965 r. odszedł na emeryturę, choć bliskie związki z Łodzią zerwał już wcześniej z powodu powrotu do Warszawy ${ }^{6}$. Jeśli W. Husarskiego traktować można jako prawdziwego założyciela łódzkiej historii sztuki, to śladów w niej pozostawił po sobie niewiele, a jej markę, obraz i specyfikę, nie tylko zresztą w pierwszym okresie funkcjonowania, tworzył właśnie M. Wallis.

${ }^{5}$ M. Wallis, Śp. Wacław Husarski, „Biuletyn Historii Sztuki” 1951, nr 2-3, s. 181-185; B. Miodońska, Husarski Wacław Teofil (1883-1951), [w:] Polski Słownik Biograficzny, t. 10: Horoch Mieczysław - Jarosiński Paweł, red. K. Lepszy, 1962-1964, s. 117-118. W haśle tym podano nie do końca prawdziwą informację, iż „w 1946 r. ciężka choroba płuc zmusiła [go] do rezygnacji z pracy naukowej”, acz prawdą jest, że aktywność profesora zdecydowanie się ograniczyła. Por. J. Kita, R. Stobiecki, Słownik biograficzny historyków łódzkich, Łódź 2000, s. 44-45; J. Kita, S. Pytlas, W służbie nauki. Profesorowie Uniwersytetu Łódzkiego w latach 1945-2004. Pro memoria, Łódź 2005, s. 134-135.

${ }^{6}$ J. Białostocki, Mieczysław Wallis (1895-1975). Wspomnienie pośmiertne, „Biuletyn Historii Sztuki" 1976, nr 2, s. 174-178; J. Kita, R. Stobiecki, op. cit., s. 98-99; J. Kita, S. Pytlas, W służbie nauki..., s. 419-421. 
Chyba najważniejsze dla poznania początkowego etapu istnienia łódzkiej historii sztuki teksty napisała jego uczennica i zarazem kontynuatorka Wanda Nowakowska ${ }^{7}$. Oprócz dwóch wyżej wymienionych profesorów wspomnieć jeszcze należy o co najmniej pięciu innych wykładowcach. Zajęcia prowadziły bowiem także osoby luźniej związane z uczelnią: znawca sztuki nowoczesnej Marian Minich, częściej kojarzony jako twórca i wieloletni dyrektor łódzkiego Muzeum Sztuki, archeolog śródziemnomorski, badacz sztuki antycznej i przedwojenny profesor Uniwersytetu Stefana Batorego Rajmund Gostkowski, historyk architektury Bohdan Guerquin, będący w tedy jeszcze doktorem Jan Białostocki, a także wywodzący się ze Lwowa wieloletni konserwator zabytków Zbigniew Ciekliński. Była to więc kadra nie tylko zróżnicowana pod względem pochodzenia i zainteresowań, sięgających od sztuki antycznej do nowoczesnej, lecz także prezentująca najwyższy poziom merytoryczny. Choroba prof. W. Husarskiego i jego rezygnacja spowodowały, że kuratorem Zakładu Historii Sztuki został w 1949 r. M. Wallis. Po śmierci profesora objął on w 1951 r. historię sztuki, a łódzka estetyka została wobec braku profesora zlikwidowana. Do 1952 r. łódzką historię sztuki ukończyło 20 osób i jeszcze 2 estetykę u prof. Husarskiego, czyli łącznie 22 osoby. Tematy ich prac magisterskich były bardzo zróżnicowane, co dobrze rokowało przyszłemu rozwojowi tego niewielkiego środowiska, w którego skład oprócz wymienionych wchodziły jeszcze trzy asystentki (K. Piechowska, K. Mierzejewska i J. Zagałowa), a także zatrudniona od roku akademickiego 1951/1952 i potem wiele licząca się w dziejach ośrodka Irena Popławska ${ }^{8}$.

W roku akademickim 1952/1953 rozwój łódzkiej historii sztuki został nagle zahamowany ministerialnym nakazem wstrzymania naboru studentów. Posiadająca nadal status samodzielnej jednostki rozpoczęła funkcjonowanie jako tzw. katedra usługowa, prowadząc tylko własne prace badawcze oraz usługi dydaktyczne i wchodząc w skład wydziału, od 1952 r. już Filozoficzno-Historycznego, a nie Humanistycznego ${ }^{9}$. Kierownikiem Katedry pozostał do 1965 r., czyli do przejścia na emeryturę, prof. M. Wallis. Po zniesieniu historii sztuki jako kierunku studiów specjalność ta weszła w Łodzi

7 W. Nowakowska, Historia sztuki na Uniwersytecie Łódzkim, „Miscellanea Łódzkie” 1990, nr 1, s. 10-15; eadem, $W$ stronę nowoczesności - historia sztuki na Uniwersytecie Łódzkim, [w:] Dzieje historii sztuki w Polsce. Kształtowanie się instytucji naukowych w XIX i XX wieku, red. A.S. Labuda, K. Zawiasa-Staniszewska, Poznań 1996, s. 266-277.

${ }^{8}$ Ze środowiskiem łódzkich historyków sztuki krótko związana była także docent Alicja Simon, wcześniej kierująca Zakładem Muzykologii.

${ }^{9}$ Ze zlikwidowanego jesienią $1951 \mathrm{r}$. Wydziału Humanistycznego powstały trzy: Filozoficzno-Społeczny, Historyczny i Filologiczny, a 11.02.1952 r. z dwóch pierwszych stworzono istniejący do dziś Wydział Filozoficzno-Historyczny, por. B. Baranowski, K. Baranowski, Trudne lata..., s. 29-30. 
w stan swojego rodzaju rozwoju utajonego. Nie tylko ona, gdyż podobne były losy łódzkiej archeologii, także, jak widać, w tamtych czasach zupełnie niepotrzebnej ${ }^{10}$. Kierunek ten miał jednak więcej „szczęścia”, gdyż dzięki energii K. Jażdżewskiego i zaangażowaniu innych osób na fali październikowej odwilży został prędzej reaktywowany, a ogólnouniwersytecki wykład inauguracyjny otwierający jesienią rok akademicki 1956/1957 w UŁ wygłosił właśnie K. Jażdżewski.

Nieszczęście, jakie dotknęło na początku lat pięćdziesiątych XX w. łódzką humanistykę, było wynikiem ogólniejszych mechanizmów, definiowanych najczęściej jako typowe dla epoki stalinizmu. W tej optyce nauka miała być tylko bronią służącą do walki ideologicznej, podporządkowaną teoretycznie państwu, a praktycznie partii komunistycznej i jej rojeniom. W skali naszej uczelni o przemianach tych najobszerniej pisali Bohdan Baranowski i Krzysztof Baranowski, jak i niedawno Rafał Stobiecki ${ }^{11}$. Pierwsi zwrócili uwagę na wielość przyczyn upadku łódzkiej uczelni, spośród nich wymienili: (1) wdrożenie państwowej koncepcji trójstopniowej gradacji uniwersytetów, w myśl której w Łodzi (w „małym uniwersytecie”) z kierunków humanistycznych pozostać miała tylko historia, nauki społeczne, filologia polska i rusycystyka (poprzednio 15 specjalności) ${ }^{12}$, (2) nieudane starania o stworzenie „socjalistycznego uniwersytetu”, (3) spory ideowe w obrębie kadry i jej odpływ do odradzającej się Warszawy, (4) konflikty z lokalnymi władzami, dla których uniwersytet był $\mathrm{w}$ robotniczym mieście tylko niepotrzebnym i zbyt kosztownym luksusem. Co ciekawe, autorzy ci dość łagodnie oceniali rządy ówczesnego rektora Józefa Chałasińskiego, sugerując szczerość intencji wprowadzania „socjalistycznego uniwersytetu”, ale też obserwując jego nadgorliwość i zarazem niezgrabność w działaniach. Nieco inaczej opisał te lata R. Stobiecki, podkreślający zasadniczą błędność koncepcji „socjalistycznego uniwersytetu w robotniczej Łodzi”. Próba jej realizacji doprowadziła do strat, tak w nauce, jak i w mieście. 0 ile w 1949 r. w UŁ uczyło się ponad 9 tys. studentów, o tyle w połowie lat pięćdziesiątych już tylko 1,5 tys. Ważną rolę w realizacji tych szkodliwych przemian odegrał ówczesny rektor (1949-1952), socjolog J. Chałasiński. Z perspektywy dziejów ocenić go można jako najgorszego rektora w historii UŁ, choć równocześnie pamiętać

10 Skalę upadku UŁ w tamtych latach dobrze ilustruje porównanie 15 specjalności, a zarazem kierunków: 7 filologicznych oraz filozofii z psychologią, nauk społecznych, pedagogiki, archeologii, etnografii, historii sztuki i muzykologii oraz historii z realizowanymi od roku 1951 i w roku akademickim 1952/53, gdy zachowały się tylko 3: historia, filologia polska i rusycystyka. Por. B. Baranowski, K. Baranowski, Trudne lata..., s. 129.

${ }^{11}$ B. Baranowski, K. Baranowski, Trudne lata..., s. 5-19; R. Stobiecki, Z dziejów pewnego projektu . „Socjalistyczny uniwersytet w robotniczej Łodzi”, „Rocznik Łódzki” 2014, t. 61, s. 153-164.

${ }^{12}$ Uniwersytetem centralnym, o znaczeniu ogólnopolskim miał być Uniwersytet Warszawski, uczelniami dużymi Kraków, Poznań i Wrocław, a małymi Lublin, Łódź i Toruń. 
musimy, że nie były to przecież lata łatwe ani przyjemne. Może to właśnie zadecydowało, że w pamiętnikach kolejnego rektora UŁ (z lat 1952-1956), Jana Szczepańskiego, który zaczął starania o podniesienie naszej uczelni $\mathrm{z}$ dna upadku, lata własnego pełnienia tej funkcji są w zasadzie pominięte ${ }^{13}$. Po obszernej relacji o roku 1948 następują wakacje roku 1953 spędzone w rodzinnym Ustroniu koło Cieszyna, następnie w zasadzie niedotyczący Łodzi opis roku 1954 i już rok 1957, czyli poza kadencją rektorską. 0 trudach kadencji dowiedzieć się można niejako pośrednio, czytając, jak w 1954 r. jeździł do Warszawy, rozmawiał z ministrami Adamem Rapackim, Henrykiem Golańskim, Eugenią Jodłowską-Krassowską i innymi politykami. Raz tylko pojawia się bardzo „łódzka” i zarazem gorzka konstatacja:

Dzwonił Litwin ze sprawozdaniem z W-wy. Jadę tam we wtorek. Znów walka o Uniwersytet Łódzki: do ministra, do wiceprzewodn. Rady Państwa Ignara - cała plejada bezsilnych dygnitarzy ${ }^{14}$.

Łagodzenie strat poczynionych w czasie kadencji rektora J. Chałasińskiego nie było, jak widać, łatwe. Rektor J. Szczepański, nie będąc w stanie zmienić kierunku wiejących z ministerstwa wiatrów, zdecydowanie poprawił jednak relacje uczelni z władzami miejskimi, a także np. przywrócił rekrutację na tak nikomu niepotrzebnym kierunku jak archeologia. Właściwą odbudowę Uniwersytetu Łódzkiego przeprowadził jednak dopiero kolejny rektor, prawnik Adam Szpunar (1956-1962) ${ }^{15}$.

Sytuacja, którą można określić jako stan utajenia łódzkiej uniwersyteckiej historii sztuki, trwała długo, nie był to jednak czas do końca stracony. W skali ogólnopolskiej wielce liczyły się kolejne publikacje M. Wallisa - wspomnę tu tylko o przygotowywanej jeszcze w „okresie łódzkim”, ale wydanej już w 1967 r. w Warszawie książce Secesja, którą zaliczyć wypada do nielicznych, bo zmieniających optykę całego środowiska polskich historyków

${ }^{13}$ J. Szczepański, Dzienniki z lat 1945-1968, wstęp, przypisy i oprac. D. Kadłubiec, Ustroń 2013. Zadziwiony tym opuszczeniem skontaktowałem się z wydawcą pamiętników, prof. D. Kadłubcem, który poinformował mnie, iż nie dokonywał jakichkolwiek generalnych redakcyjnych korekt. Wynika z tego, że albo J. Szczepański lat tych w ogóle nie opisywał (w co jestem skłonny wątpić), albo ta partia tekstu została usunięta lub znajduje się jeszcze w posiadaniu rodziny.

14 Ibidem, s. 73. Litwin to Józef Litwin, prawnik, profesor UŁ (1904-1966), a Ignar to Stefan Ignar (1908-1992), działacz ówczesnego Zjednoczonego Stronnictwa Ludowego (czyli chłopskiej partii „sojusznicznej” wobec PZPR, z którą czuł się z racji swego pochodzenia związany J. Szczepański), członek i wiceprzewodniczący Rady Państwa oraz wicepremier. Ministrem szkolnictwa wyższego był wtedy (1951-1956) Adam Rapacki (1909-1970).

15 Był też pierwszym rektorem naszej uczelni chodzącym w gronostajach, zresztą przeszytych z kupionego w komisie futra, dawniej należącego do ciotki jednej z bliskich współpracownic. 0 wadze jego kadencji dla przezwyciężenia kryzysu UŁ por. W. Puś, op. cit., s. 309-312. 
sztuki $^{16}$. Po odejściu w 1965 r. prof. M. Wallisa na emeryturę nastał trwający aż 10 lat okres niemożności podjęcia rozsądnej decyzji.

Czas ten przypominam sobie już z autopsji, bo w drugiej połowie lat sześćdziesiątych miałem okazję bywać w dusznym, zagraconym i wypełnionym do sufitu książkami lokalu historii sztuki w gmachu Biblioteki Uniwersyteckiej. Na trzecim lub czwartym roku swych studiów postanowiliśmy w ramach zajęć specjalizacyjnych z koleżanką Magdą chodzić na wykłady z historii sztuki. Początkowo było to według naszego dziekanatu w ogóle niemożliwe; potem okazało się, że jednak można, ale w Państwowej Wyższej Szkole Sztuk Plastycznych (poprzedniczce obecnej Akademii Sztuk Pięknych), gdzie kursowe wykłady miał Henryk Anders. Był to czas, gdy asystentem noszącym za profesorem na wykład książki był Ryszard Hunger, późniejszy rektor tej uczelni i do tego uznany malarz. Mimo wysłuchania całego przewidzianego w planie studiów kursu oraz egzaminu, z którego wpis znalazł się w naszych indeksach, nie utraciliśmy werwy i szukaliśmy kolejnych wykładów. Wtedy dopiero dowiedzieliśmy się, że dla tzw. wolnych słuchaczy miała je w Bibliotece Uniwersyteckiej dr I. Popławska. Prowadziła je właśnie w tym dusznym lokalu, przy stole grupującym cztery-sześć osób, mówiąc o architekturze klasycyzmu i wieku XIX w Europie. Mimo że nie były to moje ukochane epoki ani dzieła, dzięki tym wykładom do dziś kocham i podziwiam wspaniałość londyńskiego Crystal Palace, do dziś też wstydzę się tego, czego każdy student wstydzić się powinien. Wykłady odbywały się wieczorami, pokój był, jak już pisałem, duszny i mały (12 m kw.), światło trupio jarzeniowe, a ja czasami bywałem do wysłuchiwania raczej przygotowany intelektualnie niż kondycyjnie. Podczas jednego z wykładów z bardzo daleka dotarła do mnie rozmowa dwóch pań, z których jedną nazwałbym dziś spokojną, drugą jadowitą. Rozpoczęła jadowita słowami triumfu: „O, śpi!” Potem spokojna: „Nie szarp go, obudzi się sam”. Jadowita: „Ale śpi i zaraz spadnie” [zapewne z krzesła - L.K.]. Spokojna: „Nie, zaraz się obudzi i nic nie będzie wiedział o naszej rozmowie”. Głos spokojny należał do pani doktor, student rzeczywiście zaraz się obudził... i tak to nie zbadałem twardości bibliotecznego parkietu.

Sytuacja historii sztuki w UŁ po części unormowana została dopiero w 1975 r., gdy w ramach Wydziału Filozoficzno-Historycznego powołano do życia Zakład Historii Sztuki, którego kuratorem został Waldemar Michowicz, a pracownikami I. Popławska i W. Nowakowska. Obie były doktorantkami prof. M. Wallisa, przy czym I. Popławska poświęciła swą tezę architekturze przemysłowej Łodzi (1966), zaś pracująca wtedy w Państwowej Wyższej Szkole Teatralnej i Filmowej (oraz w PWSSP i w Państwowej Wyższej Szkole

16 Doczekała się ona także wydania niemieckojęzycznego jako: Jugendstil, München 1974. 
Muzycznej) i zatrudniona w UŁ w 1965 r. W. Nowakowska koncepcji krytyki artystycznej Stanisława Witkiewicza $(1965)^{17}$. Jeszcze w latach siedemdziesiątych I. Popławska przeniosła się na Politechnikę Łódzką, gdzie po habilitacji w 1983 r. została docentem, a potem profesorem. Także w 1983 r., ale w UJ, habilitację uzyskała W. Nowakowska, która w 1984 r. objęła stanowisko docenta, a w 1990 r. profesora nadzwyczajnego ${ }^{18}$.

W dniu 1 listopada 1979 r. Zakład Historii Sztuki znalazł się w strukturze Instytutu Historii, a 1 stycznia 1980 r. jego kierownictwo objęła W. Nowakowska. Natomiast pełną samodzielność łódzka uniwersytecka historia sztuki osiągnęła dopiero w styczniu 1992 r. (za czasów rektora Michała Seweryńskiego, dziekana Wiesława Pusia i prodziekana ds. nauczania Jana Szymczaka), gdy zyskała autonomię w obrębie Wydziału Filozoficzno-Historycznego. 0 aktywnych działaniach badawczych i dydaktycznych pracowników Zakładu w latach 1975-1992 obszernie pisała już W. Nowakowska i spraw tych nie będę tu rozwijać ${ }^{19}$. Nadal jednak brakowało odwrócenia decyzji stalinowskiej wiceminister E. Jodłowskiej-Krassowskiej z początku lat pięćdziesiątych o wstrzymaniu rekrutacji studentów.

Zmiana ustroju dokonana w 1989 r. nie spowodowała w naszej uczelni natychmiastowych i zasadniczych zmian. Wynikało to z kilku przyczyn. Rektorami UŁ w latach osiemdziesiątych byli profesorowie (prawnik Jerzy Wróblewski w latach 1981-1984 i fizyk Leszek Wojtczak w latach 1984-1990) mało rozbudzeni politycznie, a do tego mądrzy, rozsądni, spokojni i dbający o dobro powierzonych im ludzi i wartości ${ }^{20}$. Do tego dożywało już, przechodząc na emerytury, pokolenie pracowników mocno związanych uczuciowo z „kierowniczą rolą kompartii”, a także osoby, które oceniać można jako beneficjentów niesławnej pamięci wydarzeń marcowych $1968 \mathrm{r}^{21}$ Do pracy w UŁ przystąpili też młodzi ludzie, kombatanci znanego „łódzkiego strajku studentów". Strajk z 1981 r. nie tylko spowodował wymuszone powroty do Łodzi naszego byłego rektora, ekonomisty Janusza Górskiego (1972-1975), który teraz, jako Minister Nauki, Szkolnictwa Wyższego i Techniki (1978-1981), stał się przewodniczącym rządowej komisji do rozmów ze studentami. Ważniejsza była owocująca zmianą mentalności nauka całego

17 W. Nowakowska, Stanisław Witkiewicz - teoretyk sztuki, Wrocław 1970; I. Popławska, Architektura przemysłowa Łodzi w XIX w., Warszawa 1973.

${ }^{18}$ Na podstawie pracy: Narodowa funkcja sztuki w polskiej krytyce artystycznej lat 1863-1890, Łódź 1981.

19 W. Nowakowska, $W$ stronę nowoczesności..., s. 271-273. Por. eadem, Historia sztuki na Uniwersytecie Łódzkim. Kierunek studiów: historia sztuki na Uniwersytecie Łódzkim - otworzony na nowo, „Biuletyn Historii Sztuki” 1996, R. 58, nr 1-2, s. 227-232.

${ }^{20}$ W. Puś, op. cit., s. 332-339.

${ }^{21}$ Por. Marzec ‘68 w Łodzi, red. S.M. Nowinowski, współpraca A. Czyżewski, M. Zapolska-Downar, P. Spodenkiewicz, M. Przybysz, G. Nawrot, Łódź 2010. 
pokolenia - ludzi nie tylko wchodzących dopiero w życie, ale i stanowiących nowe kadry uczelni. Mimo mocnej jeszcze tradycji „socjalistycznej uczelni w robotniczym mieście" UŁ zaczął się ewolucyjnie zmieniać, dostosowując się do nowych realiów. Zmiana ta dokonała się za kadencji trzech rektorów: prawnika Michała Seweryńskiego (1990-1996), geografa Stanisława Liszewskiego (1996-2002) i historyka Wiesława Pusia (2002-2008) ${ }^{22}$. Tak jak A. Szpunara traktować można jako autora odrodzenia łódzkiej uczelni w czasach październikowego przełomu, tak M. Seweryński i S. Liszewski oraz kontynuujący ich linię W. Puś stworzyli teraz nową uczelnię, dostosowując ją do warunków i realiów innego ustroju. Pisząc o „nowej uczelni”, zacząć wypada od jej struktury, rozumianej nie tylko jako liczba wydziałów, specyfika prac badawczych, kierunków dydaktycznych itp. Dotąd był to trudno sterowalny twór, rozrzucony po całym mieście i użytkujący ponad 150 budynków, w większości kompletnie nieprzystosowanych do wymogów prac naukowych i dydaktyki. Rektorzy lat dziewięćdziesiątych doprowadzili do komasacji terenów i lokali uczelni w północno-wschodniej części miasta, znacznie zmniejszyli liczbę użytkowanych budynków, stawiając równocześnie nowe wielkie gmachy dla jednostek wydziałowych. Unormowano także prawne podstawy stanu posiadania należących do UŁ nieruchomości. Już za czasów rektora W. Pusia rozbudowano Bibliotekę Uniwersytecką, a niedawno, za rządów Włodzimierza Nykiela, sfinalizowano budowę gmachu Wydziału Filologii, czym w zasadzie zakończono lokalowy rozrost uczelni.

Zmieniające się realia i nowy obraz uczelni zbiegły się w czasie z przemianami znacznie bardziej ogólnymi. Założenie, że środkiem wpływającym na ograniczenie bezrobocia może być zwiększenie liczby studentów, było w zasadzie dobre, ale raczej na poziomie refleksji arytmetycznej niż znajomości skomplikowanych mechanizmów społecznych. Spowodowało bowiem lawinowy wzrost liczby osób studiujących, także odpłatnie, w ślad za czym iść musiało czasami cudowne rozmnożenie kadry nauczającej. Nie wymienię tu nazwiska klasyka, który dość dawno temu zauważył, że ilość nie przekłada się na jakość, a skutki tego działania były oczywiste. Działania uczelni stały się towarem, studiować zaczęli ludzie, którzy nie powinni nigdy zostać studentami, profesorowie pracowali na wielu etatach, a lata owego triumfalnego „podnoszenia wskaźnika scholaryzacji” przyniosły gwałtowne obniżenie poziomu działań naukowo-dydaktycznych. Dziś, gdy uczelnie borykają się z małą liczbą studentów, przynajmniej w stosunku do pracującej tam kadry, warto zastanowić się, jakie błędy popełniono wtedy i jak wyjść obronną ręką z obecnej, też niełatwej sytuacji.

${ }^{22}$ W. Puś, op. cit., s. 339-350. 


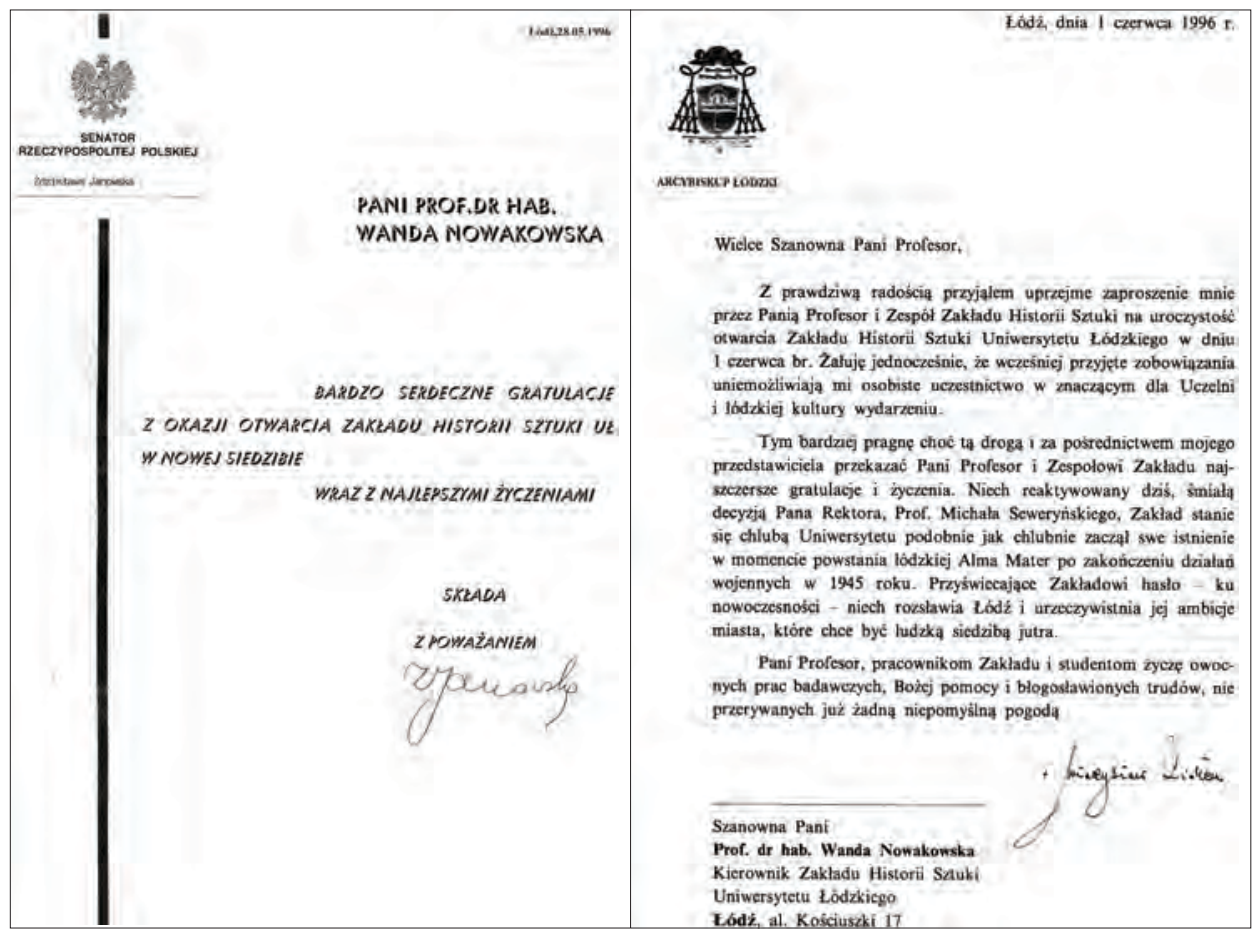

Ryc. 1-2. Fotokopie listów powstałych z okazji reaktywacji w 1996 r. studiów łódzkiej historii sztuki

Jak już wspomniałem, zarządzeniem JM Rektora UŁ prof. Seweryńskiego w roku akademickim 1992/1993 reaktywowano nabór studentów na historię sztuki. Była to nie tylko ważna decyzja dla tej specjalności i całej łódzkiej humanistyki, lecz także działanie o wymiarze prawie symbolicznym, bo zamykające pewną ramę kompozycyjną. Oto po 40 latach załamania znów powróciła triada nauczanych nauk humanistycznych: archeologii, etnografii (czyli etnologii, zwanej dziś antropologią kulturową) i właśnie historii sztuki, informująca po prostu o powrocie do uniwersyteckiej normalności. Dawny zakład, kierowany przez W. Nowakowską i zatrudniający jeszcze I. Popławską oraz Eleonorę Jedlińską, stał się teraz jednostką dydaktyczną, prędko powiększając swój stan etatowy. Jak zanotowała W. Nowakowska, poza nią w roku akademickim 1995/1996 w Katedrze Historii Sztuki pracowało na różnych etatach (także drugich lub niepełnych) w sumie 11 osób. Oprócz kierownika Katedry i zarazem osoby, bez której odrodzenie łódzkiej historii sztuki nie byłoby możliwe, byli to profesorowie: Ewa Marxen-Wolska, Grzegorz Sztabiński (potem następca W. Nowakowskiej na stolcu kierowniczym w latach 1999-2009), Zbigniew Bania, Jadwiga Lipińska i Jerzy 
Malinowski, adiunkci E. Jedlińska i Krzysztof Stefański (obecnie też już profesorowie, a ten drugi od 2009 r. pełni funkcję kierownika jednostki) oraz czterej asystenci: Piotr Gryglewski (też już profesor), K. Cichoń, K. Rutkowski i R. Wróbel. Ponadto zajęcia w różnych latach akademickich prowadzili liczni pracownicy innych jednostek, wspomnę tu tylko Ryszarda Hungera z PWSSP, Teresę Kmiecińską-Kaczmarek i Janinę Ładnowską z Muzeum Sztuki oraz Magdalenę Mączyńską, Ilonę Skupińską-Løvset i piszącego te słowa z Instytutu Archeologii UŁ.

Drugim, oprócz kadry, warunkiem działań był lokal. Mieścił się na pierwszym piętrze kamienicy przy al. Kościuszki 17, w domu, który starszym pracownikom uczelni nieodmiennie kojarzył się z akcją walki z gruźlicą. Po likwidacji uniwersyteckiego "szpitalika dziennego" i przeprowadzeniu remontu o charakterze konserwatorskim, Katedra zyskała tam nie tylko godziwe, lecz także niebanalne warunki egzystencji. Dzięki adaptacji kamienicy, wzniesionej w 1890 r. i należącej wtedy do znanego łódzkiego przemysłowca Karola Scheiblera, oprócz historii sztuki pomieszczono tam slawistykę i bibliotekoznawstwo. Czytelnika spoza Łodzi wypada tu poinformować, że lokale znajdujące się we frontowych partiach kamie-

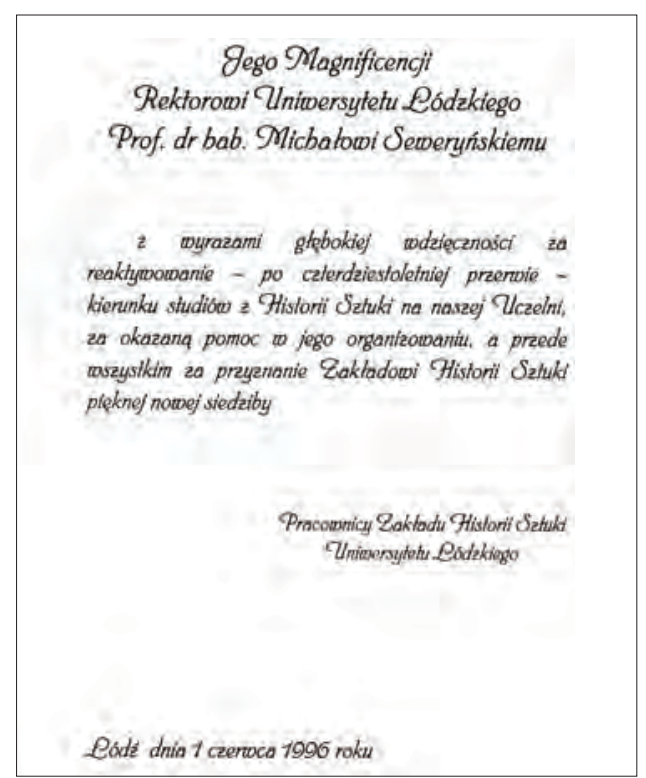

Ryc. 3. Fotokopia podziękowania pracowników JM Rektorowi prof. M. Seweryńskiemu nic stojących przy głównych ulicach naszego miasta miały bogaty wystrój, często określany wręcz jako „pałacowy", z ozdobnymi parkietami, ciemną boazerią, tkaninami na ścianach, sztukateriami na sufitach i drzwiami przeszklonymi szybkami z fazowanego kryształu. Tak też wyglądała usytuowana na pierwszym piętrze, a więc na poziomie prawdziwego piano nobile, w salonach bardzo bogatego lodzermenscha, siedziba Katedry, użytkowana od roku akademickiego 1995/1996. Frontowe pomieszczenia tych wielopokojowych mieszkań służyły codziennej egzystencji i świątecznej recepcji, ich części gospodarcze lokowane były w bocznych oficynach. Tak też było i tu, z kuchnią i łazienką w prawej oficynie; zaś wnętrzem, którego magię wspominam z pewną czułością do dziś, była właśnie konserwatorsko zrekonstruowana łazienka, wyglądająca 
chyba tak, jak 100 lat wcześniej, z oryginalnymi kafelkami na ścianach i ze wspaniałą wanną na nóżkach ${ }^{23}$. Klimat opisanego miejsca prawdziwie godny był pasji ówczesnych studentów zaangażowanych w jego porządkowanie i wręcz cyzelowanie. Tam też, oprócz codziennych zajęć, odbywały się pierwsze „fuksówki”. Pisząc o urodzie eklektycznych wnętrz, nie sposób pominąć ich przydatności dla potrzeb dydaktyki. Łączna powierzchnia użytkowana przez historyków sztuki wynosiła bowiem ponad $530 \mathrm{~m}$ kw., na co składało się łącznie 14 pomieszczeń, w tym 3 sale wykładowe (o powierzchni: 122, 65 i $41 \mathrm{~m} \mathrm{kw.)} \mathrm{i} 3$ sale seminaryjne ${ }^{24}$.

Dziś patrzę na ten etap egzystencji Katedry z wielkim żalem; zmarnowano coś tak naprawdę cennego jak ludzka inicjatywa i młodzieńczy zapał. Młyny uczelniane sprawiły bowiem, że po kilku latach Katedra przeniesiona została do prawdziwego pałacu. W al. Kościuszki 17 zadomowił się „inwestor”, którego jednym z działań była wymiana zabytkowej stolarki okiennej na nową, barwy czerwonej, która piękni neorenesansowo-neobarokową elewację kamienicy do dziś.

Pałac stanowiący nowy lokal był równie prawdziwy jak sublokatorstwo w nim Katedry Historii Sztuki. Wabiło natomiast ogrodzenie terenu, rozległy park z rododendronami i obecność wielkiego parkingu. Jednostka utraciła jednak swą „osobność”, nie zyskując na powierzchni, zaś w ostatnich latach przed kolejną przeprowadzką warunki do dydaktyki i pracy były naprawdę bardzo złe. Mając tam przez wiele lat zajęcia, z kilku przyczyn nie przywiązałem się do tego wnętrza, a zachowałem jedno smutne wspomnienie z zimnego deszczowego dnia czerwcowego w 2009 r. Od czasów kierowania Wydziałem przez dziekana Jana Szymczaka (1996-2002) corocznym naszym rytuałem stały się „spotkania wydziałowe” odbywające się w piątkowe lub sobotnie wieczory i gromadzące Koleżeństwo mające akurat chwilę czasu i ochoty, a pozytywnie nastawione do bliźnich i współpracowników. Jedni tańczyli, inni potrafili przegadać noc do białego rana. Co roku spotkanie przygotowywała inna jednostka wydziałowa; w $2009 \mathrm{r}$. wypadło na Katedrę Historii Sztuki. Pierwszy komunikat organizatorów szczerze nas zmroził, a popołudnie było potwornie zimne i w dodatku lało. Okazało się, że odnośne władze uczelni, kierując się zapewne słuszną troską o zachowanie w porządku pałacowych wnętrz, zabroniły urządzenia w nich planowanego spotkania, cedując nam tylko ogród i korytarze. Tłocząc się

${ }^{23} \mathrm{O}$ fakcie tym informował autor podpisany jako JP w artykule wydrukowanym w „Gazecie Łódzkiej”, lokalnej edycji „Gazety Wyborczej” z dnia 4.06.1996 r. Szkoda tylko, że tekst ten ma tytuł Historycy w zabytku, a nie np. Historycy sztuki w zabytku, oraz że opisywaną kamienicę ulokowano przy ul. Piotrkowskiej 17, a nie al. Kościuszki 17.

${ }^{24}$ Dane te podaję według pomiaru pierwszego piętra domu przy ul. al. Kościuszki 17 przechowywanego w archiwum Katedry Historii Sztuki. Za jego udostępnienie serdecznie dziękuję pani Jolancie Bardzińskiej. 
w korytarzu i moknąc przy grillu, wymienialiśmy cierpkie uwagi ze stojącym obok Waldkiem Ceranem, źle bardzo mówiąc o decydentach - widać wychowanych w świecie profesorów rzygających po boazeriach, zrywających w pijanym amoku tkaniny ze ścian lub może tylko niszczących parkiety i tłukących sedesy. Potem usiedliśmy gdzieś w kąciku i Waldek zainteresował się moim pobytem w Apamei, a ja jego w Antiochii. Przegadaliśmy cały wieczór i sporo dowiedziałem się, a zarazem nauczyłem od tego wielkiego znawcy świata i kultury antycznej. W poniedziałek rano już wiedziałem, że nie żyje ${ }^{25}$.

Trzecim warunkiem każdego procesu dydaktycznego jest program studiów. Wanda i Ewa nie miały poprzednio w układaniu planów zajęć studiów magisterskich specjalnych doświadczeń, ja z kolei, znając się co nieco na planach układanych dla studentów archeologii, nic nie wiedziałem o wymogach studium historii sztuki. Swe braki nadrabialiśmy przekonaniem, że musi się udać, a kłopoty wynikające z potrzeby zmieszczenia się pomiędzy obowiązującymi ministerialnymi wytycznymi programowymi, uczelnianymi limitami godzinowymi itp. a zdrowym rozsądkiem, stopniowo i mozolnie sprowadzaliśmy do wymiarów zapisu nie tylko godzinowo harmonijnego. Widać trójka jest jednak nie bez kozery cyfrą szczęśliwą, ale zapewne nie tylko dlatego nam się to wszystko udało. Opracowany wtedy plan studiów od tego czasu ulegał wielokrotnym zmianom, niezmienne jednak pozostały pryncypia, o których informowała już prof. W. Nowakowska. Pisała ona:

opracowując wstępnie program studiów [...] zastanawialiśmy się nad specyfiką naszego kierunku i sprofilowaniem zajęć. W każdym uniwersytecie w Polsce tego typu kierunek posiada własną specyfikę w zależności od regionu i charakteru miasta, w którym działa [...] Łódź poszczycić się może wspaniałymi zbiorami sztuki nowoczesnej, [...] posiada też cenne zabytki architektury XIX i początku XX w. ${ }^{26}$

I dalej: „postanowiliśmy więc wybrać jako naszą specjalizację - przede wszystkim sztukę XX w., a także w szerokim zakresie badania nad sztuką wieku XIX"27. Taka specjalizacja łódzkiej historii sztuki pozostała do dziś, a zasadność tego ukierunkowania nie budzi specjalnych dyskusji. Nie wyklucza to z jednej strony prowadzenia interesujących studiów dotyczących niesamowicie zaniedbanych badań nad architekturą i sztuką regionu sieradzkiego i łęczyckiego, a także sztuką polską, europejską i światową starszych okresów chronologicznych.

${ }^{25}$ Profesor W. Ceran zmarł nagle 20.06.2009 r.

${ }^{26}$ W. Nowakowska, W stronę nowoczesności..., s. 274.

27 Ibidem. 
Choć zapewne w niniejszym tomie znajdzie się niejeden tekst poświęcony bohaterce odrodzenia łódzkiej historii sztuki, czyli Pani Profesor Wandzie Nowakowskiej, z kronikarskiego niejako obowiązku poświęcić Jej trzeba ten krótki akapit ${ }^{28}$. Jest bowiem osobą o wielce bogatej osobowości, co trafnie ujął w swym tekście P. Gryglewski, charakteryzując swą mistrzynię jako: profesora, a więc wykładowcę akademickiego, promotora, czyli badaczkę-historyka sztuki, i wreszcie szefową, będącą inspiratorem działań i kreatorem drogi naukowej współpracowników ${ }^{29}$. Wychowana w rodzinie, którą w czasach mojego dzieciństwa określało się pojemnym hasłem „inteligencja pracująca", zdała maturę w łódzkim IV Liceum im. Emilii Szczanieckiej. Magisterium uzyskała w 1952 r., przedstawiając przygotowaną pod kierunkiem M. Wallisa pracę Teoria wyrazu u Leonarda da Vinci, doktorat w 1965 r. i habilitację w 1983 r. w UJ, a w 1990 r. została profesorem nadzwyczajnym. Opinie o dorobku umożliwiającym uzyskanie tytułu profesora napisali na początku 2000 r. profesorowie Tadeusz Chrzanowski z Krakowa, Wiesław Juszczak z UW i Instytutu Sztuki PAN oraz Andrzej K. Olszewski z Uniwersytetu Kardynała Stefana Wyszyńskiego i z UŁ. Nie będę tu wspominać o bardzo wysokich ocenach merytorycznych działań Pani Profesor oraz licznych komplementach zgodnie wypełniających wszystkie trzy teksty. Myślę jednak, że zacytowania wymaga tu jedno ze zdań, pochodzące z recenzji T. Chrzanowskiego. Brzmi ono: „Życie prof. Wandy Nowakowskiej jest przykładem nieustannej i pozytywnej aktywności" i chyba najlepiej charakteryzuje efektywność działania Jej pełnego uśmiechu życia ${ }^{30}$.

W dniu 1 kwietnia 1998 r. dawny Zakład podniesiono do poziomu katedry, a już z 21 września 1999 r. pochodzi pismo Pani Profesor do rektora UŁ z prośbą o zatrudnienie na $1 / 3$ etatu w związku z odejściem na emeryturę $^{31}$. Przełom wieków i tysiącleci był więc dotykalny także w łódzkiej uniwersyteckiej historii sztuki. Pod rządami następców W. Nowakowskiej (kolejnymi kierownikami Katedry byli, jak już wspomniałem, G. Sztabiński i K. Stefański) rozrosła się w strukturę trójzakładową (z zakładami: historii sztuki do końca XVIII w., historii architektury XIX-XX w. oraz historii malarstwa i rzeźby XIX-XX w., kierowanymi przez Z. Banię, K. Stefańskiego

${ }^{28}$ Nie zamierzam tu jednak dublować danych zawartych w książce Profesor Wanda Nowakowska, wydanej w serii „Sylwetki łódzkich uczonych”, z. 118, Łódź 2015, gdzie można znaleźć prace: E. Jedlińska, Profesor Wanda Nowakowska, s. 11-38; G. Sztabiński, Profesor Wanda Nowakowska - szkice do portretu, s. 39-47; K. Stefański, Dobre owoce, s. 49-53; A. Pawłowska, Pocztówka, s. 55-58; P. Gryglewski, Profesor. Promotor. SZEFOWA. O Pani Profesor oczami ucznia, s. 59-66.

29 P. Gryglewski, Profesor..., s. 59 i nast.

30 Opinia prof. T. Chrzanowskiego z datą: Kraków, 5.03.2000 r. przechowywana w archiwum Katedry. Za jej udostępnienie bardzo dziękuję pani J. Bardzińskiej.

${ }^{31}$ Pisma udostępnione mi przez panią J. Bardzińską, za co serdecznie dziękuję. 
i G. Sztabińskiego), raz jeszcze zmieniła mieszkanie, lokując się we wnętrzach może solidnych i obszernych, ale nie do końca gościnnych, bo... pozbawionych dostępu do parkingu; w sumie jednak nie wypadła z torów wytyczonych przez W. Nowakowską. Mimo rany widocznej na ciele łódzkiej humanistyki przez ponad 40 lat, a spowodowanej socjalistycznym eksperymentem, zachowała cechę typową dla normalnych ośrodków akademickich, rozumianą jako porządek naturalnej sukcesji. W naszym wypadku wiodła ona od twórcy ośrodka, będącego zarazem mistrzem, czyli M. Wallisa, do jego prawdziwej odnowicielki - a jednocześnie uczennicy - czyli W. Nowakowskiej.

W związku z tym, powracając do tytułu tego tekstu, mówiąc o pierwszych i drugich narodzinach łódzkiej uniwersyteckiej historii sztuki, pamiętać musimy przede wszystkim o Mieczysławie Wallisie i Wandzie Nowakowskiej.

\section{BIBLIOGRAFIA}

Baranowski B., Baranowski K., Pierwsze lata Uniwersytetu Łódzkiego (1945-1949), Łódź 1985. Baranowski B., Baranowski K., Trudne lata Uniwersytetu Łódzkiego (1949-1956), Łódź 1990. Baranowski K., Początki Łodzi akademickiej, Łódź 1993.

Białostocki J., Mieczysław Wallis (1895-1975). Wspomnienie pośmiertne, „Biuletyn Historii Sztuki" 1976, nr 2, s. 174-178.

Kita J., Pytlas S., Uniwersytet Łódzki w latach 1945-1995, Łódź 1996.

Kita J., Pytlas S., W służbie nauki. Profesorowie Uniwersytetu Łódzkiego w latach 1945-2004. Pro memoria, Łódź 2005, s. 134-135.

Kita J., Stobiecki R., Słownik biograficzny historyków łódzkich, Łódź 2000, s. 44-45.

Marzec '68 w Łodzi, red. S.M. Nowinowski, współpraca A. Czyżewski, M. Zapolska-Downar, P. Spodenkiewicz, M. Przybysz, G. Nawrot, Łódź 2010.

Materiały do dziejów Uniwersytetu Łódzkiego. 1945-1950, Łódź 1952.

Miodońska B., Husarski Wacław Teofil (1883-1951), [w:] Polski Słownik Biograficzny, t. 10: Horoch Mieczysław - Jarosiński Paweł, red. K. Lepszy, 1962-1964, s. 117-118.

Nowakowska W., Historia sztuki na Uniwersytecie Łódzkim, „Miscellanea Łódzkie” 1990, nr 1, s. 10-15.

Nowakowska W., Historia sztuki na Uniwersytecie łódzkim. Kierunek studiów: historia sztuki na Uniwersytecie Łódzkim - otworzony na nowo, „Biuletyn Historii Sztuki” 1996, R. 58, nr 1-2, s. 227-232.

Nowakowska W., Narodowa funkcja sztuki w polskiej krytyce artystycznej lat 1863-1890, Łódź 1981.

Nowakowska W., Stanisław Witkiewicz - teoretyk sztuki, Wrocław 1970. 
Nowakowska W., W stronę nowoczesności - historia sztuki na Uniwersytecie Łódzkim, [w:] Dzieje historii sztuki w Polsce. Kształtowanie się instytucji naukowych w XIX i XX wieku, red. A.S. Labuda, K. Zawiasa-Staniszewska, Poznań 1996, s. 266-277.

Popławska I., Architektura przemysłowa Łodzi w XIX w., Warszawa 1973.

Profesor Mieczysław Wallis, red. W. Nowakowska, seria „Sylwetki łódzkich uczonych”, z. 59, Łódź 2001.

Profesor Wanda Nowakowska, red. E. Jedlińska, seria „Sylwetki łódzkich uczonych”, z. 118, Łódź 2015.

Puś W., Zarys historii Uniwersytetu Łódzkiego 1945-2015, Łódź 2015.

Stobiecki R., Z dziejów pewnego projektu. „Socjalistyczny uniwersytet w robotniczej Łodzi”, „Rocznik Łódzki” 2014, t. 61, s. 153-164.

Szczepański J., Dzienniki z lat 1945-1968, wstęp, przypisy i oprac. D. Kadłubiec, Ustroń 2013.

Uniwersytet Łódzki 1945-1970, red. A. Kłoskowska, Łódź 1970.

Wallis M., Jugendstil, München 1974.

Wallis M., Śp. Wacław Husarski, „Biuletyn Historii Sztuki” 1951, nr 2-3, s. 181-185.

\section{SUMMARY}

\section{The First and the Second Birth in brief}

The topic of the present article are some remarks about the History of Art course at the University of Łódź - how it came into being, how it evolved and developed, and about the present day of the History of Art at the University of Łódź. Our Łódź University was formed in 1945 - immediately after the end of Second World War. History of Art as a subject of academic studies was also introduced at the same time in 1945. At the turning point of the two decades of the $1940^{\text {s }}$ and $1950^{\text {s }}$ our University suffered a very severe economic crisis which was symbolized by the abolition of many academic courses of studies. During this time, Humanities bore especially heavy losses, because History of Art, Archaeology and several other academic courses were completely abolished from the University. It was only three decades later, at the beginning of the $1990^{\text {s }}$ that the History of Art was finally regenerated and ever since it has been regarded as a normal academic course of the Master of Art graduates' studies at the Philosophical and Historical Department of the University of Łódź. Many people believe that Prof. Mieczysław Wallis was the founder father of our History of Art Department and if this is really true, then it must be underlined that the rebirth and revival of the History of Art studies were solely accomplished in $1990^{\text {s }}$ by a woman-professor Wanda Nowakowska. So today we can truly say that the "first birth and the second birth" of the History of Art at the University of Łódź should be foremost associated with these two extraordinary scholars and Art History experts: Prof. Wallis and Prof. Nowakowska. 